\title{
Ikke-kardial kirurgi hos hjertesyke pasienter
}

\author{
Sammendrag \\ Bakgrunn. Pasienter med hjertesyk- \\ dom har høyere forekomst av hjerte- \\ relaterte problemer etter ikke-kardial \\ kirurgi enn hjertefriske pasienter. \\ Artikkelen gir en oversikt over periope- \\ rative undersøkelser og behandling.
}

\begin{abstract}
Materiale og metode. Systematisk litteratursøk gjennom arbeid med internasjonale retningslinjer og erfaring fra egen praksis er brukt som basis for anbefalinger.
\end{abstract}

Resultater. Betablokkere bør ikke seponeres før operasjon. Oppstart av betablokade kan være fordelaktig til høyrisikopasienter før større ikke-kardiale kirurgiske inngrep. Langsom titrering av dose anbefales. Ekkokardiografi bør gjøres før preoperativ betablokade for å utelukke en latent hjertesvikt. Statiner bør vurderes før elektiv kirurgi. Indikasjon for koronarintervensjon (stenting eller kirurgi) bør vurderes før høyrisikokirurgi, men vurderes ellers uavhengig av et planlagt ikkekardialt kirurgisk inngrep. Ikke-kardial kirurgi på pasienter med ustabil koronarsykdom bør gjøres kun på vital indikasjon. Nevroaksiale teknikker er overlegne i behandling av postoperativ smerte og dermed til hjelp ved postoperativ mobilisering. Tromboseprofylakse er viktig, men øker faren for epiduralt hematom og krever systematisk oppfølging for diagnostikk og behandling.

Fortolkning. Det er lite kunnskapsgrunnlag for bruk av spesielle anestesimetoder til hjertesyke pasienter som skal ha ikke-kardial kirurgi. Stabil sirkulasjon, tilfredsstillende oksygenering, god smertebehandling, tromboseprofylakse, enteral ernæring og tidlig mobilisering bedrer det perioperative forløpet. Nært samarbeid mellom anestesiolog, kirurg og kardiolog bedrer logistikk og behandling.

\author{
Olav F. Münter Sellevold \\ olav.sellevold@ntnu.no \\ Roar Stenseth \\ Institutt for sirkulasjon og bildedannelse \\ Norges teknisk-naturvitenskapelige universitet \\ og \\ St. Olavs hospital \\ Prinsesse Kristinas gate 3 \\ 7030 Trondheim
}

Pasienter med hjertesykdom er mer utsatt enn andre for perioperative kardiovaskulære problemer ved ikke-kardial kirurgi (1-3). Stress ved kirurgi øker den nevroendokrine aktiviteten og endrer koagulasjonsstatus. Hypertensjon og takykardi sammen med hyperkoagulabilitet kan føre til hjerteinfarkt. Selv om dødeligheten er gått ned i forhold til tidligere, har perioperativt hjerteinfarkt fortsatt høy dødelighet $(8,8-29,4 \%)$ $(1,3,4)$. Det fører til et protrahert forløp for den enkelte pasient og økte kostnader for samfunnet $(1,3-5)$. Dersom risikoen på forhånd er vurdert som høy, kan man øke beredskapen eller eventuelt redusere inngrepets omfang (6-8) (ramme 1, ramme 2). God forståelse av fysiologi og patofysiologi er avgjørende for vellykket behandling. Formålet med denne artikkelen er på bakgrunn av tilgjengelig litteratur å gi anbefalinger for perioperativ vurdering og behandling hos hjertesyke pasienter som skal gjennomgå et ikke-hjertekirurgisk inngrep.

\section{Materiale og metode}

Artikkelen er basert på systematiske litteratursøk i PubMed, søk i Google, referanser i oversiktsartikler, internasjonale retningslinjer og egne kliniske erfaringer. Gjennom arbeid med europeiske retningslinjer har vi gjennomgått nyere litteratur og vektlagt randomiserte studier og metaanalyser (6). Det finnes en rekke studier om temaet ikke-kardial kirurgi ved hjertesykdom, men få med tilstrekkelig statistisk styrke til å danne basis for gode anbefalinger. De fleste anbefalinger $\mathrm{i}$ internasjonale retningslinjer bygger derfor på enighet mellom eksperter $(6,7,9)$.

\section{Preoperative undersøkelser og intervensjoner}

Stresstest kan utføres for å avdekke koronariskemi, enten ved arbeids-EKG eller gjennom betastimulering med dobutamin. Normal stresstest har høy prediktiv verdi for et kardialt ukomplisert forløp, mens en patolo- gisk stresstest med noe mindre presisjon kan forutsi et problematisk perioperativt forløp (4). Man har tenkt at positiv stresstest (påvist koronar iskemi) kan indisere koronarintervensjon før ikke-kardial kirurgi. Nyere studier viser at intervensjonsbehandling med perkutan koronar intervensjon (PCI) eller koronarkirurgi hos pasienter med stabil koronarsykdom ikke bedrer prognosen (10). Dette svekker indikasjonen for å gjøre stresstest hos stabile pasienter. Generelt vil indikasjon for koronarintervensjon ses uavhengig av et planlagt inngrep, men bør vurderes ved planlagt høyrisikokirurgi (6). Ustabilt koronarsyndrom er en klar indikasjon for koronarintervensjon før et ikke-kardialt inngrep.

Det er motstridende data om verdien av preoperativ ekkokardiografi hos ikke-symptomatiske pasienter før ikke-kardial kirurgi. Ekkokardiografi er derfor ikke nødvendig som del av utredningen med mindre man planlegger preoperativ oppstart av betablokade $(3,11)$.

Pasienter med hjerteklaffefeil har høyere risiko enn andre ved ikke-kardial kirurgi. Ved indikasjon for klaffeintervensjon bør dette gjøres først. Dersom kirurgi ikke kan vente, bør det gjøres med særskilt overvåking (6).

\section{Etter gjennomgått koronarintervensjon}

Pasienter som nylig har gjennomgått koronarintervensjon med stent utgjør en spesiell utfordring, da den antitrombotiske behand-

\section{Hovedbudskap}

- Det mangler studier med stringent metodikk og tilstrekkelig statistisk styrke som basis for råd om perioperativ behandling av pasienter med hjertesykdom

- Ved alvorlig hjertesykdom bør et samlet team vurdere å redusere omfanget av det kirurgiske inngrepet mest mulig

- Perioperativ betablokade kan være fordelaktig hos høyrisikopasienter, men oppstart må monitoreres nøye, slik at hypotensjon og bradykardi unngås

- Regionalanestesi alene eller i kombinasjon med generell anestesi gir ikke sikker reduksjon i mortalitet, men støtter et aktivt mobiliseringsregime 
lingen for å hindre stenttrombose øker blødningsfaren. Medikamentbelagte koronarstenter (drug-eluting stents, DES) har høy trombosefare dersom behandlingen med platehemmere stoppes. Det er vanlig å anbefale behandling med klopidogrel i 12 måneder, men enkelte kardiologer hevder at livslang behandling er nødvendig $(12,13)$. En nylig presentert kohortstudie fant ingen økt stenttrombose ved seponering av klopidogrel et år etter innsetting (13). Medikasjon med platehemmere utgjør en utfordring for det kirurgiske teamet og krever årvåkenhet med hensyn til kirurgisk hemostase, spesielt der en liten blødning kan gjøre stor skade, slik som ved nevrokirurgi. Det kirurgiske teamet må være oppmerksom på hvilken type stent som er brukt og legge opp behandlingen sammen med relevante spesialister. Ved akutt kirurgi vil det være behov for individuell vurdering

\section{Ramme 1}

Risikofaktorer for kardiovaskulære
komplikasjoner ved ikke-kardial
kirurgi (6-8)
= Iskemisk hjertesykdom (angina pecto-
ris/gjennomgått hjerteinfarkt)
= Hjertesvikt
= Hjerneslag eller transitorisk iskemisk
anfall (TIA)
Insulinkrevende diabetes mellitus
- Nyresvikt (kreatinin > 170)
= Alder (< 40 år, oddsratio (OR) = 1;
$>80$ år OR 19,9)
- Kirurgisk risiko (ramme 2)

\section{Ramme 2}

Risiko for kardiale hendelser og/eller død innen 30 dager etter ulike typer inngrep (6-8)
Lav risiko $<1 \%$
Brystkirurgi, endokrin kirurgi, tann-
kirurgi, øyekirurgi, gynekologiske
inngrep, mindre ortopedisk kirurgi
(som knekirurgi) og mindre urologiske inngrep
Middels risiko $1-5 \%$
Abdominalkirurgi, carotiskirurgi, peri- fer arteriell angioplastikk, endovasku- lær behandling av aneurisme, hode-/ nakkekirurgi, større ortopedisk kirurgi (som hofte, ryggrad), lungekirurgi, nyre-/levertransplantasjoner, større urologiske inngrep og nevrokirurgi
Høy risiko > $5 \%$
Aortakirurgi og større karkirurgi, peri- fer karkirurgi

der hematolog, kardiolog, anestesiolog og kirurg bør være involvert (14).

Dersom man gjør koronarintervensjon (PCI) før en planlagt operasjon, bør man bruke medikamentfri stent (bare-metal stent) som synes mindre utsatt for trombose ved seponering av platehemmere enn medikamentstentene. Etter innsetting av en slik type stent bør man sannsynligvis vente tre måneder med elektiv ikke-kardial kirurgi, selv om det ikke er god dokumentasjon bak denne anbefalingen (ramme 3).

\section{Preoperativ medikasjon}

\section{Betablokkere}

Betablokker er benyttet perioperativt i mer enn 30 år. Mangano og medarbeidere og Poldermans og medarbeidere viste i randomiserte studier at perioperativ betablokade forbedret resultatene hos hjertesyke pasienter som gjennomgikk karkirurgi $(15,16)$. Selv om det er kommet hard kritikk mot begge studiene, er bruken av betablokkere logisk og på linje med den rådende holdning til perioperativ stressreduksjon. To store randomiserte studier, DIPOM-studien med 921 diabetikere (17) og den internasjonale POISE-studien (18) med 8351 pasienter der også norske sentre deltok, førte til at den tidligere entusiasmen for perioperativ betablokade er erstattet av en mer nøktern holdning. POISE-studien viste at perioperativ betablokade reduserte antallet kardiale problemer, mens det ved 30 dagers oppfølging var statistisk signifikant økt forekomst av hjerneslag ( $1,0 \%$ versus $0,5 \%)$ og økt mortalitet $(3,1 \%$ versus $2,3 \%)$. POISE-studien er kritisert spesielt på to punkter: døgndosen av metoprolol kunne komme opp i $400 \mathrm{mg}$, noe som kan gi økt frekvens av hypotensjon med hjerneslag (11), og pasientene ble ikke vurdert med ekkokardiografi før oppstart. En preoperativ latent hjertesvikt kunne dermed ikke utelukkes.

Hjertesvikt er en sterk negativ prognostisk faktor ved ikke-kardial kirurgi (3). Selv om betablokker er et kjernemedikament i behandling av kronisk hjertesvikt, må dosen titreres opp langsomt for å unngå økende svikt. I POISE-studien fikk pasientene full dose i timene før oppstart av anestesi. Det kan derfor synes rimelig å gjøre preoperativ ekkokardiografi for å utelukke latent hjertesvikt dersom man vil starte betablokker til høyrisikopasienter før større ikke-kardial kirurgi (ramme 4). Det har vært anbefalt titrering av betablokker til hjertefrekvens 60-70 slag/min, men Bickard og medarbeidere fant $\mathrm{i}$ en metaanalyse ingen sammenheng mellom reduksjon i hjertefrekvens og gunstig virkning av betablokker (19). Derfor er det fortsatt spørsmål rundt perioperativ betablokade.

\section{Statiner}

Prospektive og retrospektive studier har indikert at statiner bedrer resultatene hos hjertesyke pasienter ved ikke-kardial kirurgi
(20, 21). Gjeldende anbefaling vil derfor være at man starter opp med statiner hos høyrisikopasienter og fortsetter med det $\mathrm{i}$ hele den perioperative perioden - inklusive operasjonsdagen (6).

\section{Andre medikamenter}

Medikamenter som angiotensin II-blokkere (AII-blokkere) og angiotensinkonvertasehemmere (ACE-hemmere) gir hypotensjon og kan redusere nyregjennomblødningen. I kasuistikker er det beskrevet svært vanskelig perioperativ hypotensjon ved bruk av disse medikamentene $(22,23)$. Vi har gode erfaringer med vår rutine som gjennom mange år har vært å seponere AII-blokkere og ACE-hemmere dagen før operasjon uansett om indikasjonen er hypertensjon eller hjertesvikt. Kalsiumantagonister kan også gi hypotensjon, men i mindre grad enn ACE-hemmere. Det er ikke omfattende dokumentasjon for å kontinuere eller seponere disse før ikke-kardiale operasjoner.

\section{Hjertesvikt}

Pasienter med hjertesvikt kan ha høye nivåer av N-terminal B-type natriuretisk peptid (pro-brain natriuretic peptide, NT-BNP) og B-type natriuretisk peptid (brain natriuretic peptide, BNP). Høye nivåer er korrelert med økt risiko for død ved ikke-kardial kirurgi (24-26). Hammill og medarbeidere undersøkte data fra en kohort på 159327 pasienter over 65 år som gjennomgikk ikke-kardiale inngrep i perioden 2000-04 (3). Pasienter som hadde fått diagnosen hjertesvikt de siste 20 måneder før ikke-kardial operasjon, hadde signifikant høyere 30 -dagers mortalitet: $8 \%$ mot $3,1 \%$ for pasienter med koronarsykdom og 2,4\% for en kontrollgruppe uten hjertesykdom $(2,3)$. Kohortstudier uten spesifikke intervensjoner egner seg til hypotesesetting, men kan ikke dokumentere at optimal behandling av hjertesvikt gir bedre prognose ved ikke-kardial kirurgi. Det er likevel et sterkt argument for å utsette planlagt ikke-kardial kirurgi til hjertesvikten er optimalt behandlet med reduksjon i indikatorer for hjertesvikt.

\section{Intraoperativ behandling}

Hemodynamisk kontroll

Takykardi, spesielt sammen med ukontrollert hypotensjon, kan gi koronar og cerebral hypoperfusjon med potensielt alvorlige konsekvenser som hjerteinfarkt og hjerneslag. Stabil hemodynamikk oppnås ikke kun gjennom valg av anestesiologisk metode, men gjennom «håndverksmessig» dyktighet (5, 27). Man vil oppnå god hemodynamisk kontroll gjennom å planlegge og å gjennomføre anestesi i forhold til stress og smertestimulering, som trakeal intubering og oppstart av kirurgi. Medvirkende til stabil sirkulasjon er adekvat væsketilførsel (Starling-mekanismen) og kontroll av kartonus gjennom bruk av vasokonstriktor og ved kontroll av hjerterytme med betablokade. En moderat dose 
noradrenalin (for eksempel 0,05 $\mu \mathrm{g} / \mathrm{kg} / \mathrm{min}$ ) vil kunne hindre vasodilatasjon og medvirke til stabilisering av pasienten gjennom det perioperative forløpet. Efedrin i små intravenøse doser $(2,5-5 \mathrm{mg})$ eller subkutant $(25 \mathrm{mg})$ kan være nyttig, selv om dette medikamentet også i lave doser en sjelden gang kan gi hypertensjon og takykardi.

\section{Målrettet hemodynamikk}

Begrepet målrettet hemodynamisk behandling (goal-directed therapy) innebærer at man forsøker å stabilisere sirkulasjonen og sikre god vevsperfusjon gjennom å styre mot faste hemodynamiske mål - enten til et definert arterielt blodtrykk, hjerteminuttvolum, et nivå for sentralvenøs metning eller intrakardialt trykk. Dette gjøres ved å gi inotrop støtte med alfa- eller betastimulerende medikamenter (noradrenalin/dobutamin) og/eller ved aktiv tilførsel av kolloid eller krystalloid væske. Ved denne behandlingen har man ofte tilstrebet supranormale verdier for oksygentransport $(>550-600 \mathrm{ml} / \mathrm{min} /$ $\left.\mathrm{m}^{2}\right)$, hjerteminuttvolum $\left(3,5-4,5 \mathrm{l} / \mathrm{min} / \mathrm{m}^{2}\right)$, blodtrykk (gjennomsnitt $>70 \mathrm{~mm} \mathrm{Hg}$ ), innkilt pulmonalarterietrykk $(\mathrm{PCWP} \sim 18$ $\mathrm{mm} \mathrm{Hg}$ ) og eventuelt en blandet venøs oksygenmetning ( $>70 \%)(28)$.

I forsøk på å nå disse definerte fysiologiske målene er det nødvendig med utvidet monitorering. Dette har gitt økt innsikt i de pågående fysiologiske prosesser under operasjonen, men uten at man sikkert kan påvise bedre behandlingsresultat. Hos pasienter med hjertesykdom er det nødvendig å få en rask indikasjon på når sirkulasjonen endres under operasjonen. Derfor vil kontinuerlig EKG-visning med ST-indikator, pulsoksimeter, timediuresemåling og intraarteriell blodtrykksmåling være standard. Vi vil også anbefale sentralvenekanylering, fordi det gir mulighet til rask behandling med vasoaktive medikamenter og væske samtidig som trykkmåling (sentralvenetrykk (CVP)) gir verdier både for intrakardiale trykk og endringer i disse trykkene. Vi anbefaler også spesielt ved større inngrep - at det gjøres måling av slagvolum og/eller blandet venøs oksygenmetning. Ingen spesiell monitorering - det være seg pulmonalarteriekateter, pulskurveanalyser, transøsofageal ekkokardiografi/dopplerundersøkelser - eller spesielle behandlingsstrategier - har med sikkerhet vist seg å bedre resultatene ved ikke-kardial kirurgi for pasienter med hjertesykdom (28). Den utvidede monitoreringen må derfor ses som metode for å forstå den pågående fysiologien bedre og en hjelp til å utvikle bedre behandlingsstrategier.

\section{Væskebehandling}

Målrettet behandling som referert til over, kan føre til stor væsketilførsel. Dette kan være årsaken til at de tidlige positive rapportene er etterfulgt av studier som viser $ø \mathrm{kt}$ komplikasjonsfrekvens (29). En liberal væsketilførsel kan gi økt tarmødem ved intra- abdominal kirurgi, noe som har stimulert til en mer restriktiv væsketilførsel. Studier der denne strategien er benyttet, har vist redusert morbiditet ved kolorektal kirurgi (30-32). Studiene har vært kritisert på grunn av valg av krystalloid væske i kontrollgruppene. Etter flere tiårs diskusjon om valg av kolloider eller krystalloider advarer flere mot en for liberal bruk av krystalloider. Det anbefales å skille mellom pasientens behov for et plasmasubstitutt på grunn av blødning (kolloid) og behov for interstitiell væske (krystalloid) $(32,33)$. Verken avansert monitorering eller standardisert væskebehandling erstatter en profesjonell og dyktig faglig anestesiologisk og kirurgisk behandling av høyrisikopasienter $(5,27,34)$. En forståelse av de forskjellige monitoreringsteknikkenes fordeler og begrensninger er nødvendig.

\section{Anestesimedikamenter}

Valg av spesifikk anestesimetode er tillagt liten vekt fordi stabil hemodynamikk er vurdert som det viktigste for et godt resultat. De fleste anestesiologiske medikamenter - både de intravenøst brukte og inhalasjonsmedikamentene - gir vasodilatasjon. Inhalasjonsmidler er viktige $i$ intraoperativ behandling for å kontrollere og stabilisere blodtrykk. Nyere litteratur kan tyde på at inhalasjonsanestesimidler har en spesifikk myokardbeskyttende virkning. Disse dataene kommer imidlertid fra dyreeksperimentelle forsøk og fra studier utført på hjertekirurgiske pasienter (35). Hjertekirurgi har en del særtrekk som gjør at man må være varsom med å trekke konklusjoner over til ikke-kardial kirurgi. Vi har ikke data som støtter anbefaling av én anestesiologisk metode fremfor en annen til hjertesyke pasienter som gjennomgår ikke-kardial kirurgi.

\section{Regional og/eller generell anestesi?}

Spinale og epidurale teknikker gir også vasodilatasjon. Når blokaden når opp til dermatom Th4, vil den hemme sympatisk stimulering av hjertet og dermed redusere hjertefrekvens og kontraktilitet. Betareseptorene vil være intakte og kan påvirkes ved å gi sympatikomimetika. Kombinasjonen av generell og regional anestesi kan - ved riktig bruk - gi stabil hemodynamikk. Pasienten vil være mer våken etter inngrepet, fordi man kan redusere bruken av intravenøse smertestillende midler. Dette er en krevende metode, og anestesiologen må være trent $\mathrm{i}$ denne formen for anestesi og være til stede under hele inngrepet for å takle de hemodynamiske utfordringene (27).

Rodgers og medarbeidere fant ved metaanalyse av tilgjengelige studier betydelig lavere perioperativ mortalitet ved bruk av regionalanestesi enn ved generell anestesi (36). Det var lavere forekomst av lungeemboli, hjerneslag og kardiale hendelser i gruppen som hadde fått regionalanestesi. Et vesentlig ankepunkt mot denne analysen er at den omfatter mange eldre studier der pasien-

\section{Ramme 3}

Perioperativ behandling av pasienter med gjennomgått $\mathrm{PCl}$ og stent $(6,12,13)$

Medikamentfri (bare-metal) stent bør foretrekkes der det er planlagt ikkekardial kirurgi

Ved elektiv kirurgi bør man vente minimum seks uker, helst mer enn tre måneder ved medikamentfri stent

Ved elektiv kirurgi bør man vente mer enn 12 måneder med medikamentbelagte stenter (Drug-Eluting Stent) dersom behandling med platehemmer må stoppes på grunn av det kirurgiske inngrepet

\section{Ramme 4}

\section{Perioperativ betablokade} ved ikke-kardial kirurgi $(6,9,11)$

Pasienter som står på betablokkere for hjertesvikt, hypertensjon eller koronarsykdom: Medikamentet gis i vanlig dose operasjonsdagen og startes så snart pasienten er hemodynamisk stabil etter operasjonen

Pasienter i høyrisikogruppe uten betablokade: Betablokkere kan gis preoperativt og bør titreres over minst en uke (helst 30 dager) under nøye observasjon. Målet er hjertefrekvens på 60-70 slag/min. Ekkokardiografi anbefales for å utelukke latent hjertesvikt, spesielt om betablokade må trappes opp raskt

Pasienter med koronarsykdom der det er påvist iskemi ved stresstest: Oppstart av betablokkere bør vurderes i forhold til typen kirurgi (ramme 2) og mulighet for perioperativ oppfølging

Lavrisikopasienter: Preoperativ oppstart av betablokade anbefales ikke

tene ikke har fått dagens tromboseprofylakse. Dette svekker konklusjonene i forhold til dagens praksis. Sprung og medarbeidere identifiserte generell anestesi som en risikofaktor for død ved karkirurgiske inngrep (1). I en prospektiv studie fra Australia randomiserte man over 900 høyrisikopasienter til generell anestesi eller per- og postoperativ epiduralanalgesi (37). Det var lavere forekomst av lungekomplikasjoner ved regionalanestesi, men mortaliteten var ikke signifikant forskjellig. Norris og medarbeidere fant heller ikke i sin randomiserte studie av pasienter til aortakirurgi forskjeller i dødelighet eller kardiale problemer (38). Wu og 
medarbeidere så på en kohort av 12817 pasienter som ble kolektomert i årene 1997-2001 (39). Den ene gruppen hadde postoperativ epidural smertebehandling $(n=2$ 253), mens dette ikke var registrert $\mathrm{i}$ den andre gruppen $(\mathrm{n}=10$ 564). Her fant man lavere dødelighet i epiduralgruppen både sju dager og 30 dager etter operasjonen. Ettersom dette var en kohortstudie, kan man vanskelig utelukke en skjevfordeling mellom gruppene både i utvelgelse og oppfølging/behandling. Det kan ha vært spesielt dedikerte anestesiologer og/eller kirurger som behandlet den gruppen som fikk epiduralbedøvelse. Det er videre et problem i tolkingen at det ikke ble funnet andre faktorer - for eksempel redusert forekomst av kardiale eller pulmonale hendelser - som kan forklare forskjellen i dødelighet. Forfatterne refererte beregninger som viste at det er nødvendig med 24000 pasienter i en høyrisikogruppe (for eksempel karkirurgi) og 1,2 millioner pasienter i en lavrisikogruppe (for eksempel hoftekirurgi) for å vise at regionalanestesi gir redusert mortalitet (39). Dette betyr i praksis at den viktigste overveielsen vil være å sikre stabil sirkulasjon og optimal postoperativ smertebehandling når man skal velge anestesiologisk metode.

Pasienter med karsykdom har overhyppighet av hjertesykdom. Ved kirurgi på arteria carotis må man stoppe blodstrømmen gjennom arterien som opereres. Ved våken pasient kan man få signal om cerebral hypoperfusjon ved at det oppstår psykiske eller nevrologiske forstyrrelser. Man kan da legge en midlertidig shunt for å bedre perfusjon. I en nylig publisert prospektiv multisenterstudie fant man likevel ikke bedre nevrologiske resultater ved bruk av lokalanestesi enn ved generell anestesi (40).

\section{Laparoskopisk kirurgi}

Laparoskopisk kirurgi gir en spesiell belastning på sirkulasjonen. Økt trykk i buken kan gi redusert tilbakestrømming av blod til hjertet, noe som gir redusert diastolisk fylning med redusert slagvolum. Hypertonikere og pasienter med aortastenose (stiv venstre ventrikkel) som har redusert diastolisk funksjon, vil være spesielt utsatt. Disse forholdene har gjort at man har frarådet denne kirurgiske teknikken til pasienter med hjertesykdom. I en liten studie der fysiologiske forandringer ble studert, ble disse reversert med intermitterende kompresjon av underekstremiteter slik at fyllingstrykket ble økt og hjertets slagvolum ble opprettholdt (41). Retrospektive studier har vist lik prognose hos pasienter med og uten hjertesykdom ved laparoskopisk kirurgi $(3,6,42)$. Det er derfor ikke holdepunkter for å fraråde laparoskopisk teknikk hos hjertepasienter, men disse må overvåkes særlig nøye under inngrepet.

\section{Postoperativ smertebehandling}

Smerte og angst vil øke sympatisk tonus, noe som kan gi koronar iskemi og forlenge tiden til full helbredelse. Det er imidlertid lite dokumentasjon for at god smertebehandling gir færre organkomplikasjoner etter kirurgi. Man skal heller ikke kunne forvente en randomisert studie av god og dårlig smertebehandling. Valg av metode for postoperativ smertelindring til pasienter med hjertesykdom må baseres på forventning om postoperative smerter, behovet for tidlig mobilisering og de forutsetningene som avdelingen har for å følge opp.

\section{Peroral og intravenøs smertebehandling}

Selv ved kombinasjon av kjente effektive metoder kan det være betydelige smerteproblemer etter større ikke-kardial kirurgi (43). Det er vanlig å gi paracetamol som basismedikasjon. Regionalanestesi vil være førstevalg der det kan forventes effekt og det ikke er kontraindikasjoner (44-48). Opioider kan gis av sykepleier etter behov, men en bedre metode er å bruke medikamenter med langsom frigiving av aktivt medikament. $\mathrm{Pa}-$ sientkontrollert analgesi (PCA) er et pumpesystem som gir opioid etter pasientens ønske innen fastsatte grenser. Pasienttilfredsheten er større ved pasientkontrollert enn ved sykepleierkontrollert analgesi, men det reduserer ikke organkomplikasjoner (49).

\section{Ikke-steroide antiinflammatoriske midler}

Bruk av ikke-steroide antiinflammatoriske midler (NSAID) i postoperativ smertebehandling er effektivt, men det er en bekymring om disse medikamentene kan medvirke til hjerte- og nyresvikt. Cox-2-hemmere sammenliknet med NSAID-preparater gir redusert risiko for gastrointestinal blødning, perioperativ blødning, bronkospasme og forsinket beintilheling. Risikoen for nyresvikt er liten for begge typer medikamenter dersom man unngår å bruke dem til pasienter med preoperativ nyresvikt eller til pasienter med dårlig vevsperfusjon $(50,51)$. Risikoen for utvikling av hjertesvikt synes å være lik for de to medikamenttypene. Begge typer medikamenter anses å være kontraindisert ved hjertekirurgi. Det er argumenter for å unngå disse medikamentene også i det perioperative forløpet ved ikke-kardial kirurgi til pasienter med nyresvikt, hjertesvikt, alvorlig angina pectoris og ved bruk av diuretika (52). Dette gjør medikamentene lite egnet til hjertesyke pasienter.

\section{Ernæring, temperatur og fysioterapi}

Dårlig ernæringstilstand hos kritisk syke er assosiert med nedsatt immunforsvar og økt tendens til infeksjoner. Disse pasientene kan ha svakere respirasjonsmuskulatur og redusert ventilasjonsevne, noe som kan føre til forlenget postoperativ respiratorbehandling. Optimal preoperativ ernæring ser ut til å bedre totalresultatet etter kirurgi, men større randomiserte studier mangler $(53,54)$.

Hypotermi kan øke blødning og gi tendens til sårinfeksjon. Postoperativ hypotermi fører til skjelving som gir økt oksygen- forbruk, noe som er uheldig for pasienter med marginal oksygentransport. Det er rimelig å sikre normotermi i den perioperative fasen (55). For hjertesyke pasienter er god oksygenering essensielt i den postoperative fasen, men det er ikke vist at supranormalt oksygentrykk er nyttig. Det er imidlertid en pågående debatt om høyt perioperativt oksygentrykk kan redusere postoperativ sårinfeksjon (56-60).

Postoperativ lungesvikt vil kunne være spesielt belastende for denne gruppen pasienter, men det er ikke vist at profylaktisk bruk av fysioterapi, økt trykk i endeekspiriet med maske (CPAP) og overtrykksventilering på maske (NIPPV) gir bedre postoperativ lungefunksjon. Alle disse metodene kan være effektive $\mathrm{i}$ behandlingen av lungesvikt etter kirurgi $(61,62)$.

\section{Oppgitte interessekonflikter: Ingen}

\section{Litteratur}

1. Sprung J, Abdelmalak B, Gottlieb A et al. Analysis of risk factors for myocardial infarction and cardiac mortality after major vascular surgery. Anesthesiology 2000; 93: 129-40.

2. Hernandez AF, Whellan DJ, Stroud S et al. Outcome in heart failure patients after major noncardiac surgery. J Am Coll Cardiol 2004; 44: 1446-53.

3. Hammill BG, Curtis LH, Bennett-Guerrero E et al. Impact of heart failure on patients undergoing major noncardiac surgery. Anesthesiology 2008. 108: $559-67$.

4. Poldermans D, Arnese M, Fioretti PM et al. Improved cardiac risk stratification in major vascular surgery with dobutamine-atropine stress echocardiography. JACC 1995; 26: 648-53.

5. Slogoff S, Keats AS. Does perioperative myocardia ischemia lead to postoperative myocardial infarction? Anesthesiology 1985; 62: 107-14.

6. Poldermans D, Bax JJ, Boersma E et al. Guidelines for preoperative cardiac risk assessment and perioperative cardiac management in non-cardiac surgery: The Task Force for Preoperative Cardiac Risk Assessment and Perioperative Cardiac Management in Non-cardiac Surgery of the European Society of Cardiology (ESC) and endorsed by the European Society of Anaesthesiology (ESA). Eur Heart J 2009; 30: 2769-812.

7. Lee TH, Marcantonio ER, Mangione CM et al. Derivation and prospective validation of a simple index for prediction of cardiac risk of major noncardiac surgery. Circulation 1999; 100: 1043-9.

8. Boersma E, Kerati MD, Schouten 0 et al. Perioperative cardiovascular mortality in noncardiac surgery: validation of the Lee cardiac risk index. Am J Med 2005; 118: 1134-41

9. Fleisher LA, Beckman JA, Brown KA et al. ACC/ AHA 2007 guidelines on perioperative cardiovascular evaluation and care for noncardiac surgery: Executive summary. J Am Coll Cardiol 2007; 50 1707-32.

10. McFalls EO, Ward HB, Moritz TE et al. Coronaryartery revascularization before elective major vascular surgery. N Engl J Med 2004; 351: 2795-804.

11. Fleisher LA, Poldermans D. Perioperative $\beta$ block ade: where do we go from here? Lancet 2008; 371 $1813-4$

12. Vik-Mo H, Slette M, Hegbom K. Antitrombotisk behandling etter perkutan koronar intervensjon med stent. Tidsskr Nor Legeforen 2008; 128: $436-9$.

13. Roy $\mathrm{P}$, Bonello L, Torguson $\mathrm{R}$ et al. Temporal relation between clopidogrel cessation and stent thrombosis after drug-eluting stent implantation. Am J Cardiol 2009; 103: 801-5.

14. Regionalanestesi ved blødningsforstyrrelser. Sentrale blokader til pasienter med økt blødnings risiko. Retningslinjer fra Norsk anestesiologisk forening. NAForum 2006; 19: 14-6 
15. Mangano DT, Layug EL, Wallace A et al. Effect of atenolol on mortality and cardiovascular morbidity after noncardiac surgery. Multicenter study of preoperative ischemia research group. N Engl J Med 1996; 335: 1713-20

16. Poldermans D, Boersma E, Bax JJ et al. The effect of bisoprolol on perioperative mortality and myocardial infarction in high-risk patients undergoing vascular surgery. N Engl J Med 1999; 341: 1789-94.

17. Juul AB, Wetterslev J, Gluud $C$ et al. Effect of perioperativ beta-blockade in patients with diabetes undergoing major non-cardiac surgery: randomised placebo controlled blinded multicentre trial. BMJ 2006; 332: 1482-9.

18. POISE Study Group. Effects of extended-release metoprolol succinate in patients undergoing noncardiac surgery (POISE trial): a randomised controlled trial. Lancet 2008; 371: 1839-47.

19. Biccard BM, Sear JW, Foëx P. Meta-analysis of the effect of heart rate achieved by perioperative betaadrenergic blockade on cardiovascular outcomes. Br J Anaesth 2008; 100: 23-8.

20. Hindler K, Shaw AD, Samuels J et al. Improved postoperative outcomes associated with preoperative statin therapy. Anesthesiology 2006; 105 : $1260-72$.

21. Dunkelgrun M, Boersma E, Schouten $O$ et al. Bisoprolol and fluvastatin for the reduction of perioperative cardiac mortality and myocardial infarction in intermediate-risk patients undergoing noncardiovascular surgery: a randomized controlled trial (DECREASE-IV). Dutch Echocardiographic Cardiac Risk Evaluation Applying Stress Echocardiography Study Group. Ann Surg 2009; 249: 921-6.

22. Comfere T, Sprung J, Kumar MM et al. Angiotensin system inhibitors in a general surgical population. Anesth Analg 2005; 100: 636-44.

23. Kheterpal S, Khodaparast O, Shanks A et al. Chronic angiotensin-converting enzyme inhibitor or angiotensin receptor blocker therapy combined with diuretic therapy is associated with increased episodes of hypotension in noncardiac surgery. J Cardiothorac Vasc Anesth 2008; 22: $180-6$.

24. Cuthbertson BH, Amiri AR, Croal BL et al. Utility of B-type natriuretic peptide in predicting medium-term mortality in patients undergoing major non-cardiac surgery. Am J Cardiol 2007; 100: $1310-13$

25. Bolliger D, Seeberger MD, Lurati Buse GA et al. A preliminary report on the prognostic significance of preoperative brain natriuretic peptide and postoperative cardiac troponin in patients undergoing major vascular surgery. Anesth Analg 2009; 108 : 1069-75.

26. Miller WL, Hartman KA, Grill DE et al. Only large reductions in concentrations of natriuretic peptides (BNP and NT-proBNP) are associated with improved outcome in ambulatory patients with chronic heart failure. Clin Chem 2009; 55: 78-84.

27. Arbous MS, Meursing AE, van Kleef JW et al. Impact of anesthesia management characteristics on severe morbidity and mortality. Anesthesiology 2005; 102: 257-68.

28. Sandham JD, Hull RD, Brant RF et al. A randomized, controlled trial of the use of pulmonaryartery catheters in high-risk surgical patients. N Engl J Med 2003; 348: 5-14.

29. Polanczyk CA, Rohde LE, Goldman L et al. Right heart catheterization and cardiac complications in patients undergoing noncardiac surgery: an observational study. JAMA 2001; 286: 309-14.
30. Brandstrup B, Tønnesen H, Beier-Holgersen R et al. Effects of intravenous fluid restriction on postoperative complications: comparison of two perioperative fluid regimens: a randomized assessor-blinded multicenter trial. Ann Surg 2003; 238 $641-8$.

31. Rahbari NN, Zimmermann JB, Schmidt T et al. Meta-analysis of standard, restrictive and supplemental fluid administration in colorectal surgery. Br J Surg 2009: 96: 331-41.

32. Johnston WE. PRO: Fluid restriction in cardiac patients for noncardiac surgery is beneficial. Anesth Analg 2006; 102: 340-3

33. Boldt J. Fluid management of patients undergoing abdominal surgery-more questions than answers. Eur J Anaesthesiol 2006; 23: 631-40.

34. Birkmeyer JD, Stukel TA, Siewers AE et al. Surgeon volume and operative mortality in the United States. N Engl J Med 2003; 349: 2117-27.

35. de Hert SG, Turani F, Mathur S et al. Cardioprotection with volatile anesthetics: mechanisms and clinical implications. Anesth Analg 2005; 100: 1584-93.

36. Rodgers A, Walker N, Schug S et al. Reduction of postoperative mortality and morbidity with epidural or spinal anaesthesia: results from overview of randomised trials. BMJ 2000; 321: 1-9.

37. Rigg JR, Jamrozik K, Myles PS et al. Epidural anaesthesia and analgesia and outcome of major surgery: a randomised trial. Lancet 2002; 359: $1276-82$.

38. Norris EJ, Beattie C, Perler BA et al. Doublemasked randomized trial comparing alternate combinations of intraoperative anesthesia and postoperative analgesia in abdominal aortic surgery. Anesthesiology 2001; 95: 1054-67.

39. Wu LC, Rowlingson AJ, Herbert R et al. Correlation of postoperative epidural analgesia on morbidity and mortality after colectomy in Medicare patients. $\mathrm{J}$ Clin Anesth 2006; 18: 594-9.

40. GALA Trial Collaborative Group. General anaesthesia versus local anaesthesia for carotid surgery (GALA): a multicentre, randomised controlled trial. Lancet 2008; 372: 2132-42

41. Bickel A, Loberant N, Bersudsky M et al. Overcoming reduced hepatic and renal perfusion caused by positive-pressure pneumoperitoneum. Arch Surg 2007; 142: 119-24.

42. Liu YY, Yeh CN, Lee HL et al. Laparoscopic cholecystectomy for gallbladder disease in patients with severe cardiovascular disease. World J Surg 2009. 33: $1720-6$

43. Dolin SJ, Cashman JN, Bland JM. Effectiveness of acute postoperative pain management: I. Evidence from published data. $\mathrm{Br} J$ Anaesth 2002; 89: 409-23.

44. Jørgensen H, Wetterslev J, Møiniche S et al. Epidural local anaesthetics versus opioid-based analgesic regimens for postoperative gastrointestinal paralysis, PONV and pain after abdominal surgery. Cochrane Database Syst Rev 2001; nr. 1: CD001893.

45. Block BM, Liu SS, Rowlingson AJ et al. Efficacy of postoperative epidural analgesia. A metaanalysis. JAMA 2003; 290: 2455-63.

46. Hantler C, Despotis GJ, Sinha R et al. Guidelines and alternatives for neuraxial anesthesia and venous thromboembolism prophylaxis in major orthopedic surgery. J Arthroplasty 2004; 19: 1004-14.

47. Hudcova J, McNicol ED, Quah CS et al. Patient controlled opioid analgesia versus conventional opioid analgesia for postoperative pain. Cochrane Database Syst Rev 2006; nr. 4: CD003348.

48. Mauermann WJ, Shilling AM, Zuo AZ. A comparison of neuraxial block versus general anesthesia for elective total hip replacement: a meta-analysis. Anesth Analg 2006; 103: 1018-25.

49. Liu SS, Wu CL. The effect of analgesic technique on postoperative patient-reported outcomes including analgesia: a systematic review. Anesth Analg 2007; 105: 789-808

50. Langford RM, Mehta V. Selective cyclooxygenase inhibition: its role in pain and anaesthesia. Biomed Pharmacother 2006; 60: 323-8.

51. Schug SA, Joshi GP. Camu F et al. Cardiovascular safety of the cyclooxygenase-2 selective inhibitors parecoxib and valdecoxib in the postoperative setting: an analysis of integrated data. Anesth Analg 2009; 108: 299-307.

52. Schug SA, Manopas A. Update on the role of nonopioids for postoperative pain treatment. Best Pract Res Clin Anaesthesiol 2007; 21: 15-30.

53. Matzi V, Lindenmann J, Muench A et al. The impact of preoperative micronutrient supplementation in lung surgery. A prospective randomized trial of oral supplementation of combined a-ketoglutaric acid and 5-hydroxymethylfurfural. Eur J Cardiothorac Surg 2007; 32: 776-82.

54. Brodner G, van Aken H, Hertle L et al. Multimodal perioperative management - combining thoracic epidural analgesia, forced mobilization and oral nutrition reduces hormonal and metabolic stress and improves convalenscence after major urologic surgery. Anesth Analg 2001: 92: 1594-600.

55. Kurz A, Sessler D, Lenhard R et al. Perioperative normothermia to reduce the incidence of surgical wound infection and shorten hospitalization. N Engl J Med 1996; 334: 1209-15.

56. Greif R, Akca O, Horn H-P et al. Supplemental perioperative oxygen to reduce the incidence of surgical wound infection. N Engl J Med 2000; 342 $161-7$.

57. Belda FJ, Aguilera L, de la Asunción JG et al. Supplemental perioperative oxygen and the risk of surgical wound infection: a randomized controlled trial. JAMA 2005; 294: 2035-42.

58. Brasel K, McRitchie D, Dellinger $P$. The risk of surgical site infection is reduced with perioperative oxygen. Can J Surg 2007; 50: 214-6.

59. Pryor KO, Fahey TJ 3rd, Lien CA et al. Surgical site infection and the routine use of perioperative hyperoxia in a general surgical population: a randomized controlled trial. JAMA 2004; 291: 79-87.

60. Quadan M, Akca O, Mahid SS et al. Perioperative supplemental oxygen therapy and surgical site infection. Arch Surg 2009; 144: 359-66.

61. Pasquina P, Tramer MR, Granier JM et al. Respiratory physiotherapy to prevent pulmonary complications after abdominal surgery: a systematic review. Chest 2006; 130: 1887-9.

62. Ferreyra GP, Baussano I, Squadrone V et al. Continuous airway positive pressure for treatment of respiratory complications after abdominal surgery: a systematic review and meta-analysis. Ann Surg 2008; 247: 617-26.

Manuskriptet ble mottatt 26.9. 2008 og godkjent 10.12. 2009. Medisinsk redaktør Siri Lunde. 